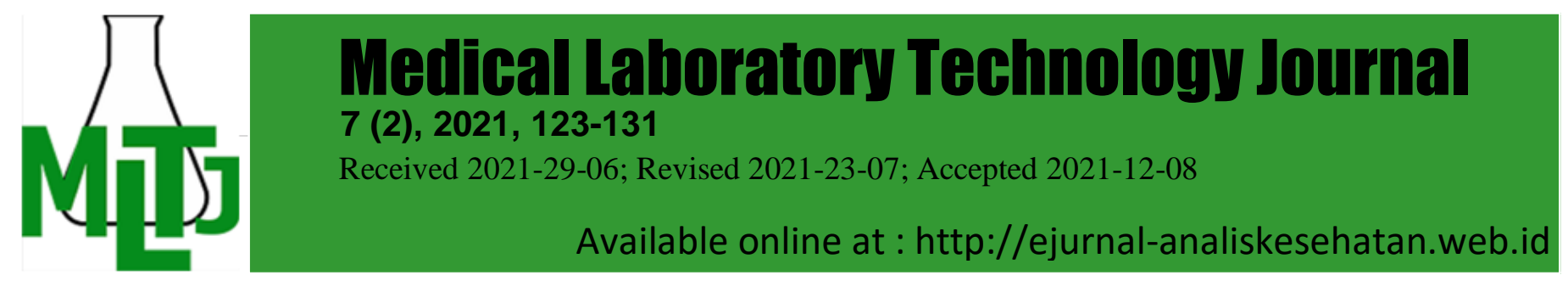

\title{
Improved Mycology Media Formula of Corn and Cow's Hair For Accelerate Superficial Mycosis Growth
}

\author{
${ }^{\star}$ Ratih Dewi Dwiyanti, Leka Lutpiatina \\ Medical Laboratory Technology Poltekkes Kemenkes Banjarmasin \\ Mistar Cokrokusumo Street 4A Banjarbaru Indonesia \\ *Email: sriyanti270363@gmail.com \\ DOI: 10.31964/mltj.v0i0.391
}

\begin{abstract}
Potato Dextrose Agar is growth and identification media of fungi that cause superficial mycoses, including Trichophyton rubrum and Trichophyton mentagrophytes with 10-14 days growth period. Modification media is needed to accelerate the growth of the fungus. Zea mays saccharata has a high carbohydrate, and cow's hair contains high keratin, which can be used as a nutrient to replace fungal growth media. The study aimed to obtain a modified media formula containing Zea mays saccharata as a substitute for dextrose and cow's hair as a source of keratin to accelerate the growth of Trichophyton rubrum and Trichophyton mentagrophytes fungi. The modified media formula is mixing of Zea mays saccharata $15 \%$ to $25 \%$, and cow's hair $20 \mathrm{mg}$ to $35 \mathrm{mg}$. Acceleration of growth time based of when found microconidia and macroconidia, diameter measurements, and observations of texture and colonies color of Trichophyton rubrum and Trichophyton mentagrophytes. The study results are Zea mays saccharata media with the addition of cow hair for Trichophyton rubrum grew 11 days with $10 \%+20 \mathrm{mg}$ formula and grew only seven days with $25 \%+35 \mathrm{mg}$ formula. Modified media for Trichophyton mentagrophytes grew seven days for $10 \%+20 \mathrm{mg}$ formula, while it was only three days with $25 \%+35 \mathrm{mg}$ formula. The media formula with the fastest growth rate for Trichophyton rubrum and Trichophyton mentagrophytes was at a concentration of $25 \%+35 \mathrm{mg}$. The Advanced Modified Media can become a patent medium for faster growth of superficial fungi at a lower cost. Further research needs to be done on how long this media can be stored for long-term use.
\end{abstract}

Keywords: Zea mays saccharata; cow hair's; Trichophyton rubrum; Trichophyton mentagrophytes

\section{INTRODUCTION}

The prevalence of superficial mycoses in Indonesia tends to increase. Identification of this mycosis-causing fungus requires a long-time laboratory culture to determine the type of species. The causative species such as Trichophyton rubrum, Trichophyton mentagrophytes, Epidermophyton floccosum take 10-14 days to be identified. The long time and limited availability of media because they are pretty expensive to diagnose superficial mycoses are rarely done by culture but primarily based on direct microscopic examination, which is used as the basis of treatment. Inappropriate treatment can lead to resistance to antibiotics.

Three genera cause dermatophytosis, namely Trichophyton, Microsporum, and Epidermophyton, grouped in the class Deuteromycetes. The three genera have found 41 species, consisting of 17 Microsporum species, 22 Trichophyton species, and 2 Epidermophyton species (Kurniati et al., 2008). Furthermore, the most common 
species causing dermatophytosis in Indonesia is Trichophyton rubrum; in addition, Trichophyton mentagrophytes and Epidermophyton floccosum are often found to cause infections. Mushroom breeding in hospital laboratories, universities, and schools in developing countries such as Indonesia has many problems due to the limitations of procuring ready-to-use instant media, which are pretty expensive and can only be obtained in certain places. In addition to the high price for breeding, it takes quite a long time. Therefore, alternative media are needed from materials that are readily available and do not require expensive costs.

One of the corn varieties in Indonesia is Zea mays saccharata. Zea mays saccharata has a sweet taste and contains high carbohydrates (Wardana, L. A., \& Syafi'i, M., 2021). The content of carbohydrates and reducing sugars in corn may replace carbohydrates and dextrose in Potato Dextrose Agar (PDA) media so that corn can be used as an alternative medium for growing mushrooms. The results of Yasirli's research (2018) using Zea mays saccharata 10\% resulted in Aspergillus niger fungal colonies with a diameter of $44.50 \mathrm{~mm}$, close to the diameter of the fungus colonies grown on PDA instant media of $57.25 \mathrm{~mm}$. The growth acceleration of Trichophyton rubrum, Trichophyton mentagrophytes, and Epidermpophyton floccosum is determined by the presence of keratin in the growth media due to the keratinophilic nature of the fungus, so it is necessary to add keratin derived from animal hair such as cow hair, cow hair is easy to obtain and has been considered useless.

Cow hair waste is produced from the livestock industry, about $1 \mathrm{~kg} / \mathrm{sheet}$ of wet skin. The cow hair waste has a reasonably high keratin protein content of around 97$100 \%$ (Sidik M., 2016). Keratin is one of the most abundant proteins found in the bodies of mammals, birds, and reptiles (Reichl et al., 2011).

Various benefits of bovine hair keratin have been used in several studies, such as for sound insulation films (Zhang Y. et al., 2018), synthetic polymer-based biomaterials, biosynthetic (Donato, R. K., \& Mija, A., 2020) for the cosmetic and pharmaceutical industry (Sharma, S., \& Gupta, A., 2016), hair protein concentrates for the provision of animal feed (Gau M. R. et al., 2021)

Trichophyton rubrum colonies grow slowly in SDA media, which is 2-3 weeks compared to Trichophyton mentagrophytes, which grow in 10 days, so identifying examinations and releasing results for treatment takes a long time (White et al., 2012). The growth of Trichophyton rubrum can be accelerated by adding keratin as a source of growth nutrients. Ademola et al. (2013) stated that Trichophyton rubrum breaks down cow hair keratin into amino acids as a source of nutrition compared to other types of keratin such as human hair, hair horses, feathers, and scales of birds.

Previous research stated that media with corn-based ingredients could grow Aspergillus $\mathrm{sp}$ with a diameter that is not much different from Sabouraud Dextrose Agar media (Yasirli H., 2019). SDA media with the addition of cow hair has also been shown to accelerate the growth of Trichophyton sp (Yulianti D, 2019). So this study designed a new media with corn as a base material and the addition of cow hair that can accelerate the growth of fungi that cause superficial mycosis of the dermatophytosis group.

\section{MATERIALS AND METHODS}

This study used an experimental method with a Post Test Only Control Group Design research design, namely by examining the growth of Trichophyton rubrum, Trichophyton mentagrophytes, and Epidermophyton floccosum grown on alternative media containing Zea mays saccharata seeds with concentrations of $10 \%, 15 \%, 20 \%$, $25 \%$ and cow's hair with a concentration of $20 \%, 25 \%, 30 \%, 35 \%$. They were then 
compared with the control, namely the growth of Trichophyton rubrum, Trichophyton mentagrophytes, and Epidermophyton floccosum grown on modified media with four repetitions.

The research materials used were Zea Mays, saccharate, and cow's hair. Zea mays saccharata research material was obtained from corn gardens in the Landasan Ulin District, Banjarbaru Municipality, Indonesia, with the criteria that the seeds did not shrivel and were clean from pests (no holes). Cow hair was purchased from a slaughterhouse in the Banjarbaru area of Indonesia. Colony samples of Trichophyton rubrum, Trichophyton mentagrophytes, and Epidermophyton floccosum colonies from the Mycology Laboratory, Faculty of Medicine, University of Indonesia.

Each medium with a predetermined concentration of Zea mays saccharata and cow's hair was inoculated with one ose of Trichophyton rubrum with the dot technique in the media center with four repetitions. This was also done for Trichophyton mentagrophytes. After being incubated at room temperature, microscopic observations were made by dripping one drop of $0.9 \% \mathrm{NaCl}$ on a glass object. One ose of fungal colonies was added, covered with a deck glass, and observed under a microscope magnification of $10 \times 40$. The length of growth time is calculated if the fungus grows perfectly (based on the presence of microconidia and macroconidia).

There are two dependent variables in this study, so the Mancova test can be done, combining ANOVA and regression tests. The requirements for homogeneity and normality tests must be met, namely homogeneous and normal data.

\section{RESULTS AND DISCUSSION}

Trichophyton rubrum was grown on Potato Dextrose Agar media as control and Zea mays saccharata media with the addition of cow's hair with various concentrations of $10 \%+15 \mathrm{mg}, 15 \%+20 \mathrm{mg}, 20 \%+25 \mathrm{mg}, 25 \%+30 \mathrm{mg}, 30 \%+35 \mathrm{mg}$ and incubated at room temperature $\left(20-25^{\circ} \mathrm{C}\right)$. Then microscopically observed every day for 14 days to see the length of time needed by the fungus Trichophyton rubrum to form macroconidia and microconidia. Macroconidia of this fungus are pencil-shaped, have groups of microconidia that are round and clustered like grapes when viewed through a microscope with a magnification of $10 \times 40$. The length of time for the growth of macroconidia, microconidia Trichophyton rubrum microscopically can be seen in table 1. In table 1, it can be seen that on Zea mays saccharata media with the addition of cow hair for Trichophyton rubrum, and the slowest growth was 11 days on $10 \%+20$ mg concentration media. In comparison, on $25 \%+35$ mg concentration media, the fastest growth was seven days. Modified media for Trichophyton mentagrophytes fungus grows the slowest seven days at a concentration of $10 \%+20 \mathrm{mg}$, while the fastest-growing is three days at a concentration of $25 \%+35 \mathrm{mg}$.

The results of measuring the diameter of the fungus Trichophyton rubrum formed on PDA control media and modified media with variations in concentrations of Zea mays saccharata and cow hair, based on table 2 it is known that the smallest diameter is in $10 \%$ corn modified media with the addition of $20 \mathrm{mg}$ cow hair, while the largest diameter is in the media modified with corn concentration $25 \%+35 \mathrm{mg}$ cow's hair.

Based on table 2, it can be seen that in the modified media Trichophyton mentagrophytes, the smallest diameter is a concentration of $10 \%+20 \mathrm{mg}$ of $2.1 \mathrm{~cm}$. In comparison, in the modified media of the fungus, Trichophyton mentagrophytes, the concentration of $25 \%+35 \mathrm{mg}$ grows with the largest diameter of $3.5 \mathrm{~cm}$. Macroscopic observations of Trichophyton mentagrophytes colonies formed on control PDA media and modified media with various concentrations. The upper part 
of the colony was textured like yellowish-white cotton and at the bottom of the colony textured yellowish on the 3rd day, then turned brownish between the 5th and 10th day.

Table 1. Length of Time For The Growth of Trichophyton rubrum on Zea mays saccharata Media and Cow Hair

\begin{tabular}{ccc}
\hline Concentration & $\begin{array}{c}\text { Growth Time Average (days) } \\
\text { Trichophyton } \\
\text { rubrum }\end{array}$ & $\begin{array}{c}\text { Trichophyton } \\
\text { mentagrophytes }\end{array}$ \\
\hline Control & 14 & 10 \\
$10 \%+20 \mathrm{mg}$ & 11 & 7 \\
$10 \%+25 \mathrm{mg}$ & 11 & 7 \\
$10 \%+30 \mathrm{mg}$ & 10 & 7 \\
$10 \%+35 \mathrm{mg}$ & 9 & 6 \\
$15 \%+20 \mathrm{mg}$ & 10 & 6 \\
$15 \%+25 \mathrm{mg}$ & 9 & 5 \\
$15 \%+30 \mathrm{mg}$ & 9 & 5 \\
$15 \%+35 \mathrm{mg}$ & 8 & 5 \\
$20 \%+20 \mathrm{mg}$ & 9 & 5 \\
$20 \%+25 \mathrm{mg}$ & 9 & 4 \\
$20 \%+30 \mathrm{mg}$ & 8 & 4 \\
$20 \%+35 \mathrm{mg}$ & 8 & 4 \\
$25 \%+20 \mathrm{mg}$ & 8 & 4 \\
$25 \%+25 \mathrm{mg}$ & 8 & 3 \\
$25 \%+30 \mathrm{mg}$ & 7 & 3 \\
$25 \%+35 \mathrm{mg}$ & 7 & 3 \\
\hline
\end{tabular}

Figure 1. Macroscopic Observations of Trichophyton mentagrophytes on Modified Media with Concentration 25\%+35 mg (The Largest Diameter) 


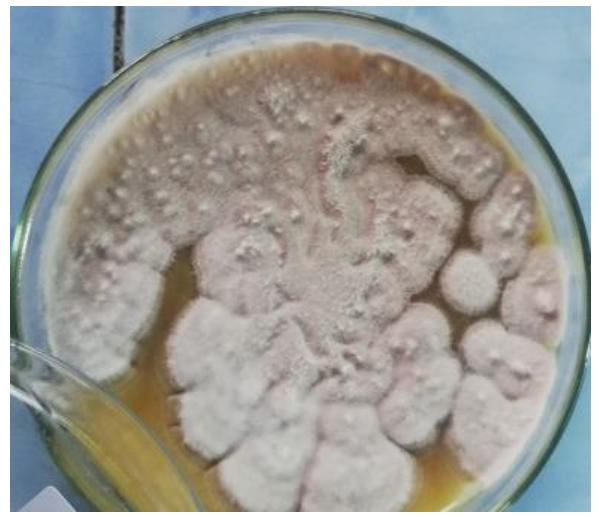

Figure 2. Macroscopic Observations of Trichophyton rubrum on Modified Media with Concentration 25\%+35 mg (The Largest Diameter)

Table 2. Results Measured the Diameter of Trichophyton rubrum Colonies on Zea mays saccharata Media and Cow's Hair.

\begin{tabular}{cccc}
\hline Concentration & $\begin{array}{c}\text { Colony Diameter } \\
\text { Trichophyton rubrum } \\
\text { (Day 14) }\end{array}$ & $\begin{array}{c}\text { Average (cm) } \\
\text { Trichophyton } \\
\text { mentagrophytes } \\
\text { (Day 10) }\end{array}$ \\
\hline \multicolumn{1}{c}{ Control } & 3,35 & 3,0 \\
& $20 \mathrm{mg}$ & 3,50 & 2,1 \\
$10 \%$ & $25 \mathrm{mg}$ & 3,65 & 2,2 \\
& $30 \mathrm{mg}$ & 4,00 & 2,3 \\
& $35 \mathrm{mg}$ & 4,15 & 2,3 \\
& $20 \mathrm{mg}$ & 3,80 & 2,4 \\
$15 \%$ & $25 \mathrm{mg}$ & 4,40 & 2,5 \\
& $30 \mathrm{mg}$ & 4,53 & 2,6 \\
& $35 \mathrm{mg}$ & 4,50 & 2,7 \\
& $20 \mathrm{mg}$ & 4,18 & 2,7 \\
$20 \%$ & $25 \mathrm{mg}$ & 4,18 & 2,8 \\
& $30 \mathrm{mg}$ & 4,35 & 2,9 \\
& $35 \mathrm{mg}$ & 4,63 & 3,0 \\
& $20 \mathrm{mg}$ & 4,58 & 3,1 \\
$25 \%$ & $25 \mathrm{mg}$ & 4,43 & 3,2 \\
& $30 \mathrm{mg}$ & 4,70 & 3,3 \\
& $35 \mathrm{mg}$ & 4,88 & 3,5 \\
\hline
\end{tabular}

Macroscopic observations of Trichophyton rubrum colonies formed on PDA control media and modified media with varying concentrations of corn and cow hair that had been incubated at room temperature were carried out every day (1×24 hours) for 14 days. Macroscopic observations included the texture of the colonies, the color of the colonies formed on the top of the media and the color of the colonies formed on the bottom of the media, and the diameter formed from day 2 to day 14 . Based on the results of the study, it can be seen that the Trichophyton rubrum fungal colonies that grew on PDA control media and modified media had a cottony texture or like 
cotton. Trichophyton rubrum fungal colonies had a yellowish-white color on the top of the media then changed to red-violet between the 4th and seventh days. The bottom of the Trichophyton rubrum colony media was yellowish on the 2nd day and then turned brown on the 5th day. Colonies on the surface of the modified media on the first day did not grow with precise characteristics. Then, the colonies were shaped like yeast with uneven distribution on the second day, so the colonies were not round. On the third day, colonies shaped like cotton will begin to appear yellowish-white with a wide diameter. The spread will continue to increase every day. The color of the redviolet colony will be visible after the fourth day. The back color of the colony will turn brown as the thickness of the colony increases.

The data in this research are all ratio scales, both dependent and independent variables. The independent variable was the concentration of cow hair and the concentration of Zea mays saccharata. In contrast, the dependent variable was the growth time and diameter of fungal colonies (Trichophyton mentagrophytes and Trichophyton rubrum). Because there are two dependent variables, the Mancova test can be done. The Mancova test combines ANOVA and regression tests; the requirements for homogeneity and normality tests are met.

Tabel 3. Normality Test Results

\begin{tabular}{ll}
\hline & Sig. \\
\hline Trichophyton mentagrophytes Growth Time & .124 \\
Trichophyton mentagrophytes Colony Diameter & $.200^{*}$ \\
Trichophyton rubrum Growth Time & $.200^{*}$ \\
Trichophyton rubrum Colony Diameter & $.200^{*}$
\end{tabular}

The normality test results were normally distributed because all $p>0.05$, the homogeneity test results from Box covariance had $\mathrm{p}=0.999$ for Trichophyton mentagrophytes and 0.988 for Trichophyton rubrum. Analysis using Mancova can be continued if $p>0.05$.

Table 4. Mantova Test Results: Variation of Treatment on Growth Time and Colony Diameter of Trichophyton rubrum and Trichophyton mentagrophytes.

\begin{tabular}{llll}
\hline Effect & & $\begin{array}{l}\text { Sig. } \\
\text { Trubrum }\end{array}$ & $\begin{array}{l}\text { Sig. } \\
\text { T menta }\end{array}$ \\
\hline Intercept & Pillai's Trace &, 000 &, 000 \\
& Wilks' Lambda &, 000 &, 000 \\
& Hotelling's Trace &, 000 &, 000 \\
& Roy's Largest Root &, 000 &, 000 \\
\hline Zea mays & Pillai's Trace &, 000 &, 000 \\
saccharate & Wilks' Lambda &, 000 &, 000 \\
Concentration & Roy's Largest Root &, 000 &, 000 \\
\hline Cow's Hair & Pillai's Trace &, 000 &, 022 \\
Concentration & Wilks' Lambda &, 000 &, 020 \\
& Hotelling's Trace &, 000 &, 018 \\
& Roy's Largest Root &, 000 &, 004 \\
\hline
\end{tabular}


Judging from the Pillai's Trace, Wilks' Lambda, Hotelling's Trace, Roy's Largest Root tests, $p<0.05$ was obtained so that it can be stated that the combination of Zea mays saccharata and cow's hair affected the colony diameter and growth time of Trichophyton mentagrophytes and Trichophyton rubrum. How big the effect is seen from its $\mathrm{R}$ squared. $\mathrm{R}$ squared for the length of growth of Trichophyton rubrum is 0.824 , or it can be interpreted that the magnitude of the influence of the two independent variables is $82.4 \%$. At the same time, for Trichophyton mentagrophytes, it is 0.863 or $86.3 \%$. For the colony diameter, Trichophyton rubrum has an R squared of 0.512 , or the effect is $51.2 \%$, while for Trichophyton mentagrophytes, it is 0.758 or $75.8 \%$. From the descriptive data, the colony diameter of the largest Trichophyton mentagrophytes was $3,256 \mathrm{~mm}$ at a concentration of $25 \%+35 \mathrm{mg}$. At the same time, the fastest growth of Trichophyton mentagrophytes started at a concentration of $25 \%+25 \mathrm{mg}$, i.e., three days. The largest colony diameter against Trichophyton rubrum was $4.875 \mathrm{~mm}$ at a concentration of $25 \%+35 \mathrm{mg}$, while the fastest growth of Trichophyton rubrum at a concentration of $25 \%+35 \mathrm{mg}$ was seven days.

Based on the results of statistical tests, it is known that the higher the concentration of corn and cow hair, the faster the growth of Trichophyton rubrum and Trichophyton mentagrophytes fungi. This shows that the modified media using Zea mays saccharata and cow's hair can accelerate the growth of the two fungal species. Zea mays saccharata can support the growth of the fungus. This is because Zea mays saccharata has a high carbohydrate content, carbohydrate substances in corn kernels contain reducing sugars (glucose, fructose) about $5-6 \%$, sucrose $11 \%$, and starch (starch) consisting of amylose and amylopectin 10-11\% in 100 grams. In fungal growth media containing carbohydrates, the fungus will secrete an a-amylase enzyme to convert starch into glucose; the glucose compound will then be absorbed by the fungus so that these nutrients can only be utilized after the fungus secretes extracellular enzymes that can decompose complex compounds from the substrate into simpler compounds (Ahmad et al., 2019). Yulianti's research (2019) showed that Trichophyton rubrum on Sabouroud Dextrose Agar (SDA) media with the addition of cow hair showed the fastest growth time of 2.5 days with the addition of $30 \mathrm{mg}$ of cow hair mass.

Meanwhile, in this study, the addition of mass of $30 \mathrm{mg}$ and $35 \mathrm{mg}$ of cow hair fungus Trichophyton rubrum requires a growth time of 7 days. This is probably due to research using cornflour containing starch so that it takes time to break down into glucose that fungi can use, this is following Getas (2014) statement that the presence of glucose can increase fungal growth, but in modified media, the source of carbohydrates comes from the content of carbohydrates. The fungus must break down starch to become glucose which can be used for energy needs in the fungus. So that the growth of fungi on Zea mays saccharata media with the addition of cow hair has a longer growth time because the fungus needs to change the complex compounds present in Zea mays saccharata into simpler compounds be used as nutrients for fungal growth. Carbon sources are helpful as energy for various fungi informing cells. During the growth process, fungi require a source of nutrients in simple compounds to be easily absorbed by the mycelium. In this case, the fungus will secrete enzymes to break down complex compounds into simpler ones. The mycelium will release extracellular enzymes into the substrate. These enzymes will degrade complex compounds into simpler ones, and the mycelium will absorb these simple compounds as energy for growth.

Trichophyton rubrum and Trichophyton mentagrophytes are keratinophilic microorganisms that produce keratinase enzymes. Keratin is found in hair, nails, 
claws, horns, and all epidermal products. One source of high enough keratin is cow hair. The cow hair used before being put into the media was first soaked using $30 \%$ $\mathrm{KOH}$. Soaking cow hair using $30 \% \mathrm{KOH}$ to soften cow hair so that it can be homogeneous when put into cow hair media. $\mathrm{KOH}$ is used because it can break down keratin so that it is easier for fungi to digest keratin as a nutrient for their growth. The fungus Trichophyton rubrum breaks down bovine hair keratin more into amino acids as a source of growth nutrients than other types of keratin. The growth of Trichophyton rubrum grows faster on Zea mays saccharata media with cow hair than control PDA media. Trichophyton rubrum will stimulate or induce large amounts of proteases (keratinase) only when grown on media containing keratin (Bitencourt et al., 2016). Keratenase secreted by fungi catalyzes the degradation of keratin into polypeptides or amino acids that the fungus can assimilate. Complex organic substances such as amino acids present in degraded keratin are used for growth, including spores (macroconidia and microconidia) (Silva and Benham, 1952).

In this study, the Zea mays saccharata media was added with cow hair. The results showed that the growth of Trichophyton rubrum and Trichophyton mentagrophytes colonies was faster than PDA media. Ademola et al. (2013) stated that the fungus Trichophyton mentagrophytes breaks down the keratin of cow hair into amino acids as a source of growth nutrients. Trichophyton mentagrophytes become faster than on the control PDA media. Therefore, bovine hair keratin added to Zea mays saccharata media can be an option in shortening the time of cell culture examination in patients, especially patients with dermatophytosis where one of the causes is the fungus Trichophyton mentagrophytes.

This research is limited to Trichophyton rubrum and Trichophyton mentagrophytes species. So it is not known the growth of fungi that cause other dermatophytoses such as Microsporum and Epidermophyton. Another limitation is that the resulting media has not yet become ready-to-use standard media and can be stored for a long time.

\section{CONCLUSION}

The modified medium formula Zea mays saccharata with the addition of cow hair obtained the fastest growth results for Trichophyton rubrum ( 7 days) and Trichophyton mentagrophytes ( 3 days) with a concentration of $25 \%+35 \mathrm{mg}$. Advanced Modified Media for Corn, Cow hair Agar, has the potential to become a patent medium for faster growth of superficial fungi at a lower cost. Further research needs to be done on the length of time this media is stored for long-term use.

\section{ACKNOWLEDGEMENT}

Thanks to all contributors for this research to be done

\section{CONFLICT OF INTEREST}

The authors declared no conflict of interest.

\section{REFERENCE}

Ademola, R. R., Omolade Olabowale, A., Folorunso Jamiu, B., Oluwadun, A., \& Onilude, A. A. (2013). Comparative study of keratinolytic activities of dermatophytes in various keratin substrates. Virol Mycol, 2(117), 2161-0517.

Ahmad, A. F., Sulaeman, S., Mulia, Y. S., \& OW, S. J. (2019). The Use of Kluwih Seed Flour (Artocarpus communis) as a Carbohydrate Source for Alternative Media for 
Growing Trichophyton rubrum. Jurnal Riset Kesehatan Poltekkes Depkes Bandung, 11(1), 337-343.

Bitencourt, T. A., Macedo, C., Franco, M. E., Assis, A. F., Komoto, T. T., Stehling, E. G., ... \& Fachin, A. L. (2016). The transcription profile of Trichophyton rubrum conidia grown on keratin reveals the induction of an adhesin-like protein gene with a tandem repeat pattern. BMC genomics, 17(1), 1-14.

Donato, R. K., \& Mija, A. (2020). Keratin associations with synthetic, biosynthetic, and natural polymers: An extensive review. Polymers, 12(1), 32.

Gau, M. R., Said, M. I., \& Yuliati, F. N. (2021, June). Effect of differences in fermentation process methods of cattle hair waste on the properties of hair protein concentrate. In IOP Conference Series: Earth and Environmental Science (Vol. 788, No. 1, p. 012153). IOP Publishing.

Getas, I. W., Wiadnya, I. B. R., \& Waguriani, L. A. (2014). Effect of addition of glucose and incubation time on sda media (saboraud dextrose agar) on the growth of candida albicans. Media Bina IIm, 8(1), 51-7.

Korniłłowicz-Kowalska, T., \& Bohacz, J. (2011). Biodegradation of keratin waste: theory and practical aspects. Waste management, 31(8), 1689-1701.

Kurniati, Cita, Rosita, S.P. (2008). Etiopatogenosis Dermatofitosis, Berkala IImu Kesehatan Kulit dan Kelamin, Universitas Airlangga, Surabaya.

Reichl, S., Borrelli, M., \& Geerling, G. (2011). Keratin films for ocular surface reconstruction. Biomaterials, 32(13), 3375-3386.

Sharma, S., \& Gupta, A. (2016). Sustainable management of keratin waste biomass: applications and future perspectives. Brazilian Archives of Biology and Technology, 59.

Sidik, M. (2016). Chemical Characteristics of Feather Flour Waste Processing of Cowhide Crackers Using $\mathrm{NaOH}$ and Different Soaking Time. Thesis. Universitas Hasanuddin Makassar.

Silva, M., \& Benham, R. W. (1952). Nutritional studies of the dermatophytes with particular reference to Trichophyton Megnini Blanchard 1896 and Trichophyton gallinae (Megnin 1881) comb. Nov. Journal of Investigative Dermatology, 18(6), 453-472.

Wardana, L. A., \& Syafi'i, M. (2021). Performance of Several Sweet Corn (Zea mays L. saccharata) M3 Generation Mutant Lines Based on Morphological Characters and Yield Power. Jurnal Agrotek Indonesia (Indonesian Journal of Agrotech), 6(1), 73-79.

White, T., Henn, M., et al. (2012). Genomic Determinants of Infection Competence in Dermatophyte Fungi. The Fungal Genome Initiative.

Yasirli H. (2019). Ability of Sweet Corn Seed (Zea mays saccharate) as a Substitute for PDA on Aspergillus niger Growth. Thesis. Poltekkes Kemenkes Banjarmasin

Yulianti D, (2019). Effect of Addition of Cow Hair on Sabouraud Dextrose Agar (SDA) Media on the Acceleration of Growth Time of Trichophyton rubrum. Thesis. Poltekkes Kemenkes Banjarmasin

Zhang, Y., Zhang, B., \& Shan, Z. (2018). Preparation of sound-insulating material based on discarded cow hair. Journal of Applied Polymer Science, 135(23), 46332. 